\title{
MODEL PEMBELAJARAN PENGELOMPOKAN KECIL DENGAN MEMBACA, MELIHAT, DAN MEMPRAKTEKKAN TERHADAP HASIL BELAJAR PADA SISWA SMK
}

\author{
Florensius P. Suseno ${ }^{1}$, Wowo S. Kuswana ${ }^{2}$, Tatang Permana ${ }^{3}$ \\ Departemen Pendidikan Teknik Mesin \\ Universitas Pendidikan Indonesia \\ Jl. Dr. Setiabudhi No. 207 Bandung 40154 \\ sherlockholmeschris@gmail.com
}

\begin{abstract}
ABSTRAK
Tujuan dari penelitian ini adalah untuk mengetahui perkembangan hasil belajar peserta didik yang menggunakan model pembelajaran M3 dengan peserta didik yang menggunakan model pembelajaran ceramah. Model pembelajaran Membaca, Melihat, dan Mempraktekkan (M3) merupakan model pembelajaran yang disesuaikan dengan karakteristik siswa SMK. Penelitian ini menggunakan metode penelitian Quasi Experimental, dengan obyek penelitian siswa kelas TKR XI. Hasil dari model pembelajaran kelompok kecil dengan model pembelajaran membaca, melihat dan mempraktekkan (M3) memperoleh nilai rata-rata 75,86\%, dan dengan model pembelajaran ceramah hanya mencapai nilai rata-rata 69,35\%. Kesimpulan penelitian ini yaitu terdapat peningkatan hasil belajar peserta didik kelas eksperimen mencapai rata-rata N-Gain 0,47.
\end{abstract}

Kata kunci: rem, model pembelajaran M3, pengelompokan, hasil belajar.

\section{PENDAHULUAN}

Pencapaian tujuan Nasional dalam mencerdaskan kehidupan bangsa sesuai dengan pembukaan UUD 1945 dilakukan melalui jalur pendidikan yang mengutamakan kegiatan belajar dan proses pembelajaran. Proses belajar-mengajar merupakan hal yang harus menjadi perhatian utama dalam penyelenggaraan pendidikan di suatu instansi pendidikan, baik pada jenjang pendidikan dasar, pendidikan menengah pertama, pendidikan menengah atas, maupun pendidikan tinggi. Proses pembelajaran merupakan salah satu tahapan yang sangat menentukan keberhasilan belajar siswa.

Sekolah Menengah Kejuruan (SMK) merupakan bagian dari pendidikan menengah dalam sistem pendidikan nasional dengan tujuan utama menyiapkan peserta didik untuk memasuki lapangan pekerjaan tertentu, serta mengembangkan sikap profesional. SMK diharapkan mampu dalam memenuhi kebutuhan pasar dunia kerja di masing-masing bidang keahlian, mampu berkompetensi dan mampu mengembangkan diri untuk mencapai taraf hidup yang lebih baik.

\footnotetext{
${ }^{1}$ Mahasiswa Departemen Pendidikan Teknik Mesin FPTK UPI

${ }^{2}$ Dosen Departemen Pendidikan Teknik Mesin FPTK UPI

${ }^{3}$ Dosen Departemen Pendidikan Teknik Mesin FPTK UPI
} 
Kualitas hasil belajar-mengajar di SMK juga memiliki hubungan yang sangat erat dengan pelaksanaan pembelajaran di kelas atau di laboratorium. Upaya meningkatkan mutu hasil belajar dan pengajaran dapat dilakukan melalui berbagai pengembangan dan perbaikan komponen seperti: siswa, guru, tujuan pembelajaran, isi pembelajaran, metode, media dan evaluasi (Winataputra, 2003). Upaya pengembangan SMK dapat juga melalui perkembangan program keahlian yang relevan dengan kebutuhan pasar tenaga kerja. Program keahlian inilah yang menjadi ujung tombak terciptanya link and match antara SMK dan dunia kerja.

Tujuan SMK harus sejalan dengan keinginan dari dunia industri terhadap kualitas tenaga kerja. Peserta didik pun dibekali dengan keterampilan, pengetahuan dan sikap kerja yang harus berkompeten dalam dunia industri. Berdasarkan dari pengamatan pembelajaran di SMK, khususnya pembelajaran di Sekolah Menengah Kejuruan Otomotif, sebagian besar proses belajar mengajar masih menggunakan metode ceramah (banyak teori) dengan sedikit praktek, sedangkan peserta didik SMK Otomotif lebih senang untuk langsung praktek.

Kejadian tersebut mengakibatkan motivasi belajar peserta didik yang awalnya sangat ingin mengetahui dan ingin memperbaiki atau memelihara mobil atau sepeda motor menjadi cenderung tidak peduli atau malas, ketika diberi materi dengan ceramah yang lama. Kejadian ini menyebabkan tujuan pembelajaran tidak tercapai dengan maksimal. Sehingga lulusannya kurang berkompeten untuk menjadi seorang mekanik junior.

Nilai hasil pembelajaran peserta didik menjadi sangat rendah karena para guru tidak memiliki metode belajar yang variasi, terutama pada mata pelajaran pemeliharaan sistem rem dengan kompetensi dasar chasis. Para peserta didik menggampangkan pembelajaran pemeliharaan sistem rem, karena peserta didik menganggap mudah materi pembelajaran pemeliharaan sistem rem dan jarangnya peserta didik untuk membaca buku pembelajaran sehingga hasil pembelajaran tidak maksimal (Sagala, 2003).

Pelajaran pemeliharaan sistem rem merupakan pembelajaran yang sangat penting dan tidak bisa diabaikan, karena kompetensi sistem rem itu harus dimiliki oleh peserta didik. Pembelajaran pemeliharaan sistem rem merupakan pembelajaran bagaimana sistem rem dapat berfungsi dengan baik dan benar, agar pengendara dapat menghindari kecelakaan dalam berkendara. Kriteria ketuntasan minimal pada mata pelajaran sistem rem adalah 70 . Hasil data ujian pemeliharaan sistem rem terdapat $16,67 \%$ peserta didik yang dinyatakan tuntas, sedangkan $83,33 \%$ siswa dinyatakan belum tuntas.

Peneliti mencoba mencari informasi saat sedang melakukan Program Latihan Profesi di salah satu SMK Otomotif, Sekolah Menengah Kejuruan Negeri 6 Bandung, yaitu mengenai 
kebiasaan membaca peserta didik, khususnya membaca teori pada mata pelajaran produktif. Waktu membaca para peserta didik sangatlah kecil, mereka akan membaca bila guru memberikan tugas pada saat jam pembelajaran saja dan disaat keesokan akan diadakan ujian. Waktu membaca peserta didik diluar jam pembelajaran saat sedikit peserta didik yang membaca buku, atau mengingat kembali pembelajaran yang telah diberikan oleh guru.

Tujuan penelitian untuk mendapatkan gambaran hasil belajar peserta didik, mendapatkan informasi ada tidaknya peningkatan hasil belajar peserta didik pada standar kompetensi pemeliharaan sistem rem, dan memperoleh informasi perbedaan rata-rata hasil belajar pada peserta didik yang menggunakan model pembelajaran M3 dengan peserta didik yang menggunakan model pembelajaran ceramah.

Model pembelajaran membaca, melihat dan mempraktekkan (M3) adalah model pembelajaran yang baru di Indonesia. Model pembelajaran ini dikembangkan oleh Wowo Sunaryo K., yang merupakan salah satu dosen pada Depertemen Pendidikan Teknik Mesin Universitas Pendidikan Indonesia. Model pembelajaran membaca, melihat, dan mempraktekkan merupakan model pembelajaran yang disesuaikan dengan karakteristik siswa SMK.

Tujuan SMK adalah menyiapkan peserta didik untuk memasuki lapangan pekerjaan serta mengembangkan sikap profesional agar mampu memenuhi kebutuhan pasar tenaga kerja. Karakteristik siswa SMK adalah malas untuk membaca atau terlalu banyakan teori, mereka lebih senang untuk langsung praktek. Kenyataan yang terjadi di lapangan adalah mayoritas guru di SMK mengajar dengan banyak teori sehingga mengakibatkan siswa kurang termotivasi dalam belajar.

\section{METODE PENELITIAN}

Metode penelitian yang digunakan dalam penelitian ini adalah metode penelitian kuasi eksperimen (quasi experimental design). Metode ini digunakan untuk mencari hubungan sebab akibat kehidupan nyata. Dimana pengendalian perubahan sulit atau tidak mungkin untuk dilakukan, pengelompokan secara acak mengalami kesulitan, dan sebagainya.

Tujuan dari metode kuasi eksperimental adalah menyelidiki ada tidaknya hubungan sebab akibat serta seberapa besar hubungan sebab akibat tersebut dengan memberikan perlakuan (treatment) pada beberapa kelompok eksperimental dan menyelidiki kontrol untuk perbandingan. Penelitian eksperimental dapat menguji hipotesa serta untuk menemukan hubungan kausal yang baru. 


\section{HASILPENELITIAN}

Hasil penelitian (Tabel 1) menunjukkan bahwa ada peningkatan selama eksperimen dilakukan. Data pada kelas eksperimen lebih baik dari kelas kontrol. Hasil perhitungan N-gain menunjukkan bahwa kelas eksperimen yaitu 0,57 lebih dari kelas kontrol yaitu 0,54.

Tabel 1. Hasil Penelitian

\begin{tabular}{ccc}
\hline Ukuran Statistik & Kelolpok Eksperimen & Kelompok Kontrol \\
\hline Rata-rata & 0,46 & 0,37 \\
Std Deviasi & 0,18 & 0,17 \\
Varians & 5,74 & 5,4 \\
$\chi_{\text {hitung }}$ & 5,93 & 21,203 \\
$\chi_{\text {tabel }}^{2}$ & 7,81 & 11,3 \\
P-V & 0,13 & 0,12 \\
$\alpha$ & 0,05 & 0,05 \\
\hline
\end{tabular}

\section{PEMBAHASAN}

Hasil belajar siswa kelompok eksperimen yaitu XI TKR 4 diberi pelakuan dengan menggunakan pembelajaran M3. Penelitian ini dilakukan beberapa tahapan yaitu pre test, treatment dan post test. Hasil belajar siswa dapat diperoleh setelah melakukan proses pembelajaran yang di ukur melalui tes, tes ini dilakukan dua kali yang pertama pre test (tes sebelum melakukan pembelajaran) dan post test (tes setelah melakukan proses pembelajaran).

Kemampuan awal siswa sebelum melakukan proses pembelajaran dapat dilihat pada diagram dibawah ini, diagram tersebut menunjukkan bahwa tidak ada perbedaan yang signifikan kemampuan awal siswa sebelum menerima materi pembelajaran antara kelas eksperimen dan kelas kontrol. Hal ini terbukti dengan dilakukan uji homogenitas data pre test yang menunjukkan bahwa kedua kelas tersebut homogen.

Perbedaan yang signifikan terlihat pada hasil post test yang dilaksanakan setelah proses pembelajaran. Hasil belajar model pembelajaran M3 memiliki indeks prestasi kelompok sebesar 75,86 pada kategori tinggi. Hasil ini sesuai dengan yang dijelaskan oleh Wowo Sunaryo K tentang model pembelajaran M3 yaitu dimulai dengan siswa membaca, kemudian melihat guru mendemontrasikan benda yang akan dipraktekkan dan mempraktekkan apa yang telah didemontrasikan oleh guru. Hasil prestasi pada kelas kontrol yang menggunakan metode ceramah.memiliki indeks prestasi kelompok sebesar 69,21 pada kategori sedang. 
Hasil analisis untuk data peningkatan pemahaman konsep diperoleh nilai rata-rata gain kelompok eksperimen sebesar 0,457 sedangkan nilai rata-rata gain kelas kontrol sebesar 0,375. Perolehan nilai rata-rata gain didasarkan pada peningkatan pemahaman konsep peserta diklat setelah menerima pembelajaran. Hasil analisis peningkatan pemahaman konsep siswa berdasarkan perhitungan rata-rata $N$-Gain kelompok eksperimen pada kategori tinggi yaitu 0,457 dan kelompok kontrol dikategorikan sedang yaitu 0,375. Model pembelajaran M3 dalam proses pembelajaran maka akan berpengaruh positif terhadap peningkatan pemahaman konsep yang lebih baik. Hal ini sesuai dengan pernyataan Hake, (2012) mengembangkan sebuah alternatif untuk menjelaskan peningkatan hasil belajar yang disebut gain normalisasi ( $N$-gain).

Hasil uji hipotesis menunjukan bahwa $\mathrm{t}_{\text {hitung }}=1,34<\mathrm{t}_{\text {tabel }}=2,04$ maka $\mathrm{H}_{0}$ diterima dan $\mathrm{H}_{\mathrm{A}}$ ditolak, artinya terdapat perbedaan rata-rata pada prestasi belajar antara siswa yang menggunakan model pembelajaran M3 dengan siswa yang menggunakan metode ceramah. Ditinjau dari hasil analisis IPK, kelompok eksperimen memiliki nilai 75,86 lebih tinggi dari kelompok kontrol dengan nilai 69,21. Berdasarkan kategori tafsiran IPK, kelompok eksperimen diketegorikan tinggi sedangkan kelompok kontrol dikategorikan sedang. Prestasi belajar siswa dapat dilihat dengan penafsiran tentang prestasi kelompok, dimaksudkan untuk mengetahui kemampuan siswa terhadap materi yang telah diteskan dengan mencari indeks prestasi kelompok (Rusman, 2011). Perhitungan statistik dengan uji-t untuk sampel independen (tidak berkorelasi) dengan jenis data interval, uji hipotesis yang digunakan adalah uji $t$-test.

\section{KESIMPULAN}

Kesimpulan penelitian ini yaitu hasil belajar peserta didik yang menggunakan model pembelajaran M3 tergolong tinggi. Ada peningkatan hasil belajar peserta didik dengan model pembelajaran M3 yaitu rata-rata $N$-Gain 0,47 dengan kategori sedang. Terdapat perbedaan yang cukup signifikan hasil belajar yang menggunakan model pembelajaran membaca, melihat dan mempraktekkan (3M).

\section{DAFTAR PUSTAKA}

Hake, R. R. (2012). Relationship of individual student normalized learning gains in mechanics with gender, high school mathematics and spatial visualization (online). Tersedia: http: //www.phsc_indiana. Edu/hake [20 juni 2012]. 
Rusman. (2011). Model-Model Pembelajaran Mengembangkan Profesionalisme Guru. Jakarta: PT. Raja Grafindo Persada.

Sagala, S. (2003). Konsep Dan Makna Pembelajaran. Bandung: Alfabeta.

Winataputra, U.S. (2003). Strategi Belajar Mengajar. Jakarta: Pusat Penerbitan Universitas Terbuka. 